Int. J. Dev. Biol. 53: 1597-1608 (2009)

doi: $10.1387 / \mathrm{ijdb} .072423 \mathrm{da}$

\title{
Instructive roles for hormones in plant development
}

\author{
DAVID ALABADÍ, MIGUEL A. BLÁZQUEZ*, JUAN CARBONELL, CRISTINA FERRÁNDIZ \\ and MIGUEL A. PÉREZ-AMADOR \\ Instituto de Biología Molecular y Celular de Plantas (UPV-CSIC), Universidad Politécnica de Valencia, Valencia, Spain
}

\begin{abstract}
Plants, like animals, construct their body following modular sets of instructions that determine cell fate, morphogenesis and patterning, among other building requirements. Hormones regulate plant growth in different ways, and there is increasing evidence for a decisive function of certain hormones in the establishment of developmental programs, equivalent to the role of peptidic molecules and signals of another nature in animal embryo development. Here, we review this role of hormones as instructive agents, and illustrate it with examples such as the generation of morphogenetic gradients by auxin (which determine organ patterning and phyllotaxis), the specification of cell fate at the shoot meristem by gibberellins and cytokinins, the switch between alternative developmental programs (photo- and skotomorphogenesis) by gibberellins and brassinosteroids, and the decision between pistil senescence or fruit growth after anthesis.
\end{abstract}

KEY WORDS: gibberellin, auxin, cytokinin, patterning, differentiation

\section{Hormones in plant development}

Since the discovery of the first few plant hormones, these compounds have been attributed numerous roles regulating the physiology, growth responses caused by stress and development of plants. However, they do not always act as their metazoan counterparts, for which the term "hormone" was coined. One of the basic differences is that, unlike in animals, plant hormones are not synthesized in a particular and specialized organ and then transported to the target organs. Rather, the ability to synthesize hormones is general to all plant tissues, and very often hormones act in the same cells where they are produced (Bishopp et al., 2006).

Plant hormones are also referred to with the generic name of plant growth regulators, to stress the fact that their function as a group is not restricted to precise physiological processes. For instance, auxins have been shown to increase cell division rate; gibberellins and brassinosteroids promote cell expansion; abscisic acid induces the physiological state of dormancy; and ethylene is required for the maturation of fleshy fruits. Nevertheless, there is increasing evidence that hormones act in many cases as an "instructive" signal in plant development, and this particular role is surprisingly similar to the action driven by peptide hormones and proteins during animal development, such as Notch and BMP (Ehebauer et al., 2006, Raftery and Sutherland, 2003). The key issue is that, in this instructive role, plant hormones do not act as mere transducers or messengers of other higher rank signals, nor do they promote growth in general. Instead, the information provided by these hormones is the basis for deciding between two alternative developmental programs, or establishing domains of identity within a given tissue.

In this review, we wish to underscore the role of hormones as instructive signals in plant development, illustrating it with only a few examples: how auxin acts as a bona fide morphogen in establishing symmetry, organ positioning and ovary construction; how gibberellins (GAs) participate in the regulatory loop that maintains stem cell populations and generates new organs; and how GAs and other hormones are key components of the molecular switches that decide between alternative developmental programs, such as photo- vs. skotomorphogenesis, and fruit set vs. ovary senescence. Moreover, we will pay attention to the structural and functional characteristics that may explain the choice of these particular molecules in plants to perform the required instructions during the evolution of developmental programs.

\section{Morphogen gradients that establish territories: auxin on the move}

Auxins play a pivotal role during plant morphogenesis: auxin

\footnotetext{
Abbreviations used in this paper: BR, brassinosteroids; CK, cytokinin; GA, gibberellin; IAA, indoleacetic acid; PAT, polar auxin transport; SAM, shoot apical meristem.
}

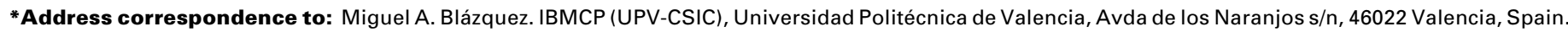
Fax: +34-96387-7859. e-mail: mblazquez@ibmcp.upv.es
}

Final author-corrected PDF published online: 24 November 2008 
asymmetric distribution throughout the plant body directs a wide array of developmental responses and processes such as embryo patterning, vascular differentiation, root and shoot patterning, tropisms or branching. Across plant tissues, it is possible to find peaks of auxin concentration and gradients at different positions and developmental stages. Auxin levels depend on the synthesis rate of this hormone, which occurs preferentially in particular locations, but also on both auxin conjugation, which renders pools of inactive auxin that can be easily mobilized by deconjugating enzymes, and on active polar transport, which ultimately enables auxin precise distribution and gradient formation and maintenance. In the last few years, our knowledge on the mechanisms of auxin signaling and action has increased steadily, with the identification of the auxin receptors, the genetic networks which allow the precise interpretation of auxin positional signaling and the characterization of proteins involved in the polar transport of this hormone

In plants, the active auxin hormone is indoleacetic acid (IAA), a small organic molecule with an indole group, soluble in aqueous solutions and also able to cross membranes. These characteristics should allow rapid diffusion from auxin sources to the surrounding tissues and the dissipation of concentration differences. However, auxin shows a clear asymmetric distribution throughout the plant that changes dynamically, as has been demonstrated through different experimental approaches, such as direct inmunolocalization with anti-IAA antibodies (Aloni et al., 2006, Aloni et al., 2003, Benkova et al., 2003), direct measurements of auxin concentration (Esmon et al., 2006, Friml et al., 2002), or
A
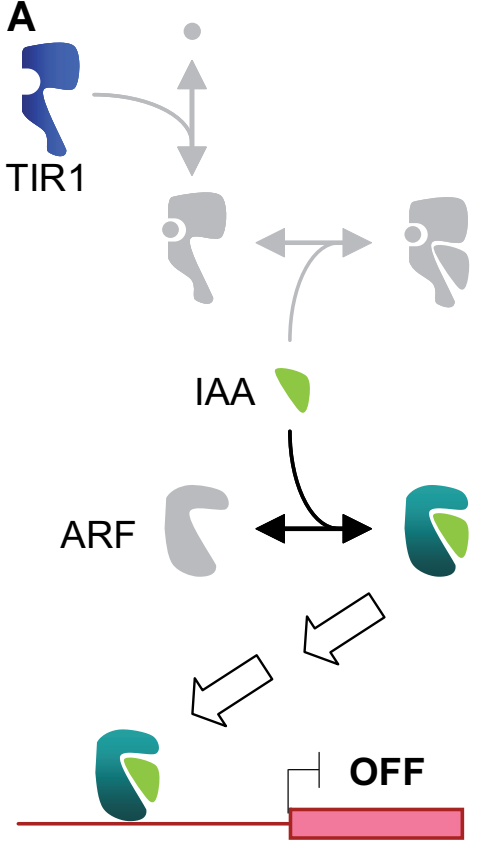

Auxin responsive gene
B
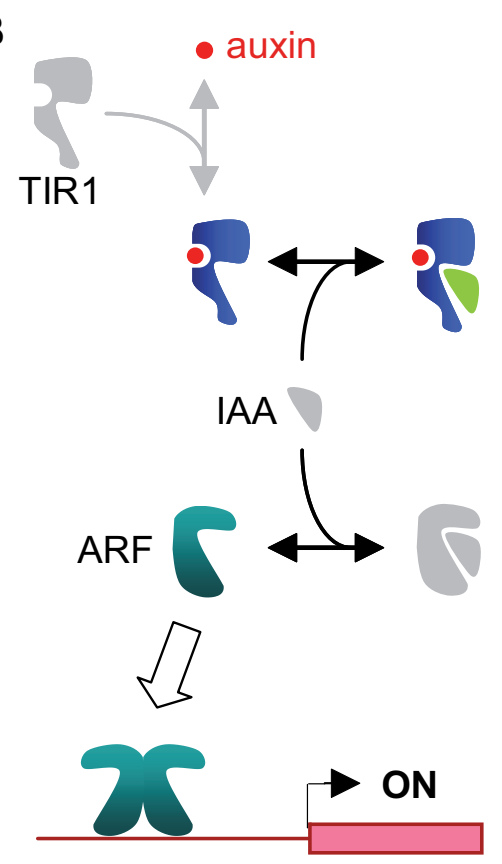

Auxin responsive gene
Fig. 1. Mechanism of auxin signaling. (A) Heterodimerization between auxon response factor (ARF) and Aux/IAA (indoleacetic acid) proteins prevents the activation of auxin responsive genes. (B) Under conditions of high auxin concentration, the transport inhibitor response1 (TIR1) auxin receptor facilitates the ubiquitination of Aux/IAA proteins and thus their proteolytic degradation by the proteasome. ARF transcription factors are then able to homodimerize and activate gene expression. Grey color represents low levels. detecting the activity of auxin-responsive reporter constructs (Aloni et al., 2003, Benkova et al., 2003, Friml et al., 2003, Sabatini et al., 1999). Auxin moves throughout the plant body by two different mechanisms. In the first one, auxin is uploaded to the phloem from source tissues like young leaves and meristematic regions, and rapidly distributed to sink tissues like the root warup et al., 2001). The second mechanism involves a slower sponsible for the establishment and maintenance of auxin peaks and gradients. Polar auxin transport (PAT) depends on the activity influx and efflux carriers that frequently show asymmetric the PINFORMED (PIN) transporter proteins, which in Arabidopsis re encoded by a gene family of 8 members (Benkova et al., 2003, et al., 2005, Friml et al., 2002, Friml et al., 2003). Each PIN a plasma membrane protein that exhibits a polarized localization. These transporters are subject to strict regulation in response to (he main one the control of PIN polarization can create currents and waves of auxin, pinpointing specific locations with sharp auxin concentration maxima or forming smoother gradients across tissues or organs. This highly dynamic and complex map is then translated by the auxin response gene network to elicit specific developmental responses.

Auxin treatments provoke the immediate upregulation of many genes. Several of them belong to the so-called Aux/IAA family, which in Arabidopsis is composed of 29 members (Liscum and Reed, 2002). Aux/IAA genes encode nuclear proteins with short half-lives, specially in the presence of auxin (Zenser et al., 2001). The fact that dominant mutations in $A u x /$ IAAgenes cause dramatic phenotypes typical of a deficient auxin response indicates that these proteins are negative regulators of auxin action (Gray et al., 2001, Ramos et al., 2001). In the promoters of $A u x / I A A$ genes, as well as in the promoter of other auxin responsive genes, one or more auxin-responsive elements (AuxRE) are usually found (Ulmasov etal., 1995, Ulmasov et al., 1997b). The transcription factors that bind AuxRE and promote gene expression in response to auxin are encoded in Arabidopsis by the 23 members elements of the AUXIN RESPONSE FACTOR (ARF) family (Okushima et al., 2005). They are sufficient to drive auxin inducible expression in synthetic reporter constructs. Aux/IAA proteins can form homo and heterodimers, but it is their interaction with ARF proteins which is instrumental for translating auxin signals into specific developmental responses, since the transcriptional activity of the ARF on its target promoters is blocked by the interaction with an Aux/IAA partner (Kim et al., 1997, Weijers et al., 2005a). Besides ARF transcription factors and Aux/IAA proteins, a third key element in the signal-response cascade is the auxin receptor, which happens to be an F- 

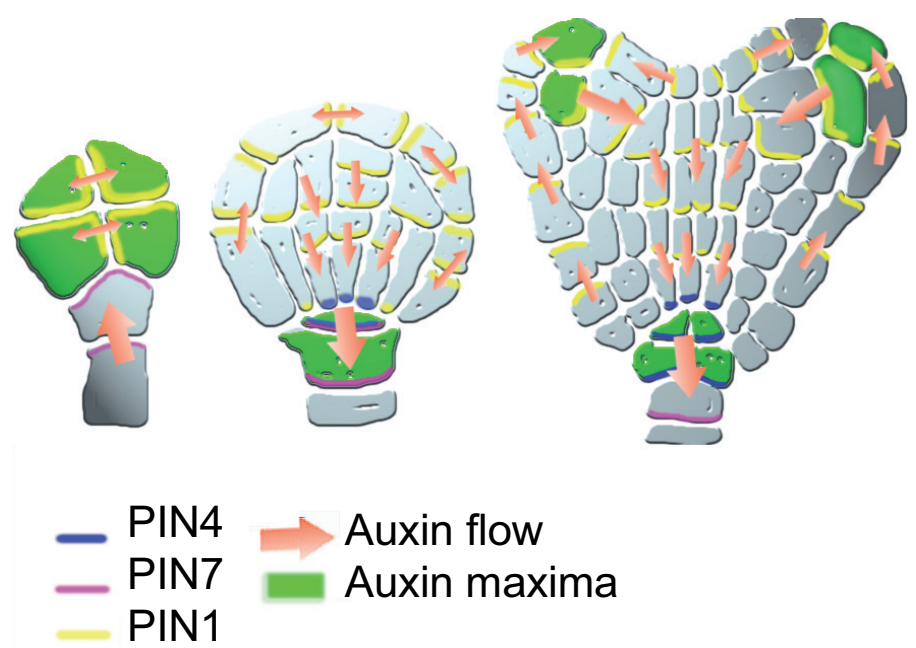

Fig. 2. Schematic representation of auxin flow patterns in a developing embryo. Polar auxin transport is directed by the different subcellular localization of three pinformed (PIN) transporters at different stages of embryo development, creating transient auxin maxima that provide positional information. First, auxin coming from maternal tissues accumulates in the early embryo. Then, auxin flux is reversed towards the base of the globular embryo creating a new maximum that promotes radicule development. At heart stage, polarization of PIN transporters at the periphery causes accumulation of auxin at lateral positions that will specify cotyledon emergence.

box protein that forms part of an SCF complex that ubiquitinates Aux/IAA repressors in response to auxin (Dharmasiri et al., 2005a, Kepinski and Leyser, 2005). The major auxin receptor in Arabidopsis is TRANSPORT INHIBITOR RESPONSE 1 (TIR1), although it is partially redundant with at least three other F-box proteins (Dharmasiri et al., 2005a, Dharmasiri et al., 2005b, Ruegger et al., 1998).

These three elements are the basis to translate auxin signals into transcriptional responses (Fig. 1). At low auxin levels, Aux/ IAA proteins are more stable, interact with ARF partners inactivating them and therefore block AuxRE-containing promoter activity (Kim et al., 1997, Ulmasov et al., 1997a, Ulmasov et al., 1997b). Higher auxin concentrations direct Aux/IAA interaction with TIR1 and related $\mathrm{F}$-box proteins, and their subsequent degradation by the proteasome, which in turn releases ARF transcription factors and they can act on their target genes. Since many AuX/IAAgene promoters contain AuxRE elements, the active ARF factors feedback on Aux/IAA levels by modulating Aux/IAA gene transcription. As discussed before, ARF, Aux/IAA and F-box proteins belong to large families and exhibit both overlapping and specific expression patterns, as well as different affinities for proteinprotein interaction. This basic network is thus provided with an exquisite combinatorial system to produce spatial and temporal specific quantitative responses to a single signaling molecule. Next, we provide some examples where auxin signaling controls developmental processes.

\section{Positional information: assymmetric distribution of auxin in neighbour cells}

The vast majority of the adult plant organs and structures derives from postembryonic development through meristem activity. However, the mature embryo is a polar structure where the major axis of symmetry, the apical-basal axis, provides the major positional clue for the development of the shoot and root meristems. There is increasing and mounting evidence of auxin being a driving force for axis formation. For instance, mutations in MONOPTEROS (MP), an ARF, or BODENLOS (BDL), an Aux/ IAA protein, prevent basal embryo development (Hamann et al., 2002, Hardtke and Berleth, 1998). When $m p$ mutations are combined with mutations in NONPHOTOTROPHIC HYPOCOTYL4 (NPH4), another ARF protein, the embryo is unable to develop both apical and basal domains (Hardtke et al., 2004). In addition, multiple combinations of mutations in PIN transporters, which are differentially expressed in the zygote up to globular stage embryos, can lead to complete loss of apical-basal polarity.

Auxin concentrations and flux direction during embryo development change dynamically and peak at specific positions in a spatial and temporal pattern that correlates with decisions in early embryo development (Fig. 2). This flux is primarily determined by the changing expression and subcellular polarized patterns of PIN transporters. Following the first asymmetric division of the zygote, PIN activity is localized in the basal cell uploading the upper cell of the embryo with auxin produced by maternal tissues, which accumulates during several rounds of cell division. At early globular stage, PIN transporters reverse polarity and redirect flux towards the basal end, creating an apical-basal flow and generating the initial of the root meristem. Subsequent reversals in the polar localization of PIN transporters in the periphery of the embryo creates two side apical auxin maxima, which mark the site of cotyledon initiation and therefore also determine bilateral symmetry (Friml et al., 2003). The MP/BDL gene network has been identified as the major response element to these auxin maxima, and in turn, it also feeds back in the system by regulating PIN gene expression (Weijers et al., 2005b, Weijers et al., 2006). However, it is likely that other yet unidentified pairs of ARF-Aux/ IAA proteins are involved in further auxin responses in the embryo. While other auxin-independent patterning networks and signaling mechanisms have been proposed to complement and further refine auxin roles in embryo patterning, there is little doubt about auxin being the major player in this game. But once the territories have been established, other hormones participate in the maintenance of this state, as we will see below.

\section{Regulatory interactions that maintain undifferentiated cells: cytokinins and gibberellins}

A very clear example of how hormones can be part of the finetuning mechanism that determines cell fate is the involvement of GAs and cytokinins (CKs) in the mainenance of stem cells. Continuous growth and formation of new organs throughout the whole life of the plant requires the activity of two small groups of cells called the shoot apical meristem (SAM) and the root apical meristem. Central to meristem function is both the ability of these cells to maintain an undifferentiated state, and also to produce differentiated cells at the flanks of the meristem that will give rise new organs and tissues. Meristematic cells are therefore plant stem cells (Weigel and Jurgens, 2002). Genetic analysis, mainly in Arabidopsis, has identified several key components of the regulatory networks that maintain the activity of the SAM: 
WUSCHEL (WUS), CLAVATA1-3 (CLV1-3), and the KNOTTED1-like homeobox (KNOX) proteins SHOOTMERISTEMLESS (STM) and BREVIPEDICELLUS (BP) (reviewed in (Weigel and Jurgens, 2002). WUS activity promotes stem cell fate, whereas the activity of the $C L V$ genes form a feedback mechanism that represses WUS expression outside the stem cell niche, thus regulating the overall size of the SAM. As a consequence, while wus mutants lack meristem, different $c / v$ mutants show enlarged meristems. Overlapping with this regulatory network there exists another one, which includes STM and BP activities, that participates in inducing meristem identity, and therefore preventing meristematic cells to acquire leaf cell fate. This is achieved by meristem-specific, STM-mediated inhibition of ASYMMETRIC $\angle E A V E S 1$ ( $A S 1)$ expression, which is normally located at the leaf primordium where it in turn represses expression of meristem identity genes. For instance, stm mutants do not initiate or maintain SAM and misexpression of $B P$ in leaves induces the formation of multiple ectopic meristems, whereas as 1 mutation disrupts the formation of cotyledons, leaves, and floral organs.

How do these regulatory networks coordinate meristem activity? The answer has brought hormone pathways to the front row in the story. CK hormones, which are anti-senescent hormones and induce cell proliferation in organ regeneration, are instrumental to bring about the activity of the two regulatory networks involved in meristem function, WUS/CLV and STM BP, as we will see now. Expression of several ARR(ARABIDOPSISRESPONSE REGULATOR) genes (the ones which act as negative elements in the CK signaling pathway) is directly repressed by WUS, suggesting that $\mathrm{CK}$ activity has a positive effect on meristem function (Leibfried et al., 2005). Indeed, over-expression of a constitutively active version of $A R R 7$ induces arrest of meristematic activity, as occurs in wus mutants. Participation of CK signaling intermediates in meristem function was also observed in maize (Giulini et al., 2004), since the mutant abphy/1, which has defects in controlling meristem size and phyllotaxy, was shown to encode a homolog of ARR proteins. The cloning of the gene affected in the rice mutant lonely guy (log) has added another

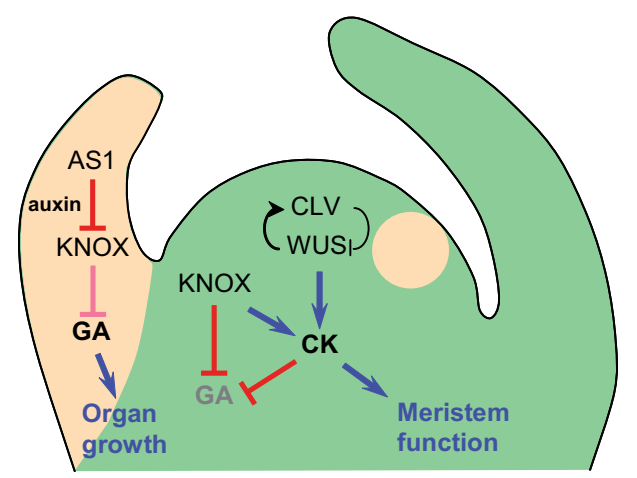

Fig. 3. Participation of hormones in meristem identity. The regulatory loop formed by WUS and CLV genes maintains the undifferentiated state of stem cells in the shoot apical meristem partly by promoting cytokinin (CK) signaling. This promotion is reinforced by at least one member of the KNOX family. Gibberellin (GA) function is repressed at the meristem by CK and KNOX by inhibiting GA biosynthesis. On the other hand, emerging primordia suffer an increase in GA activity because the product of the AS1 gene and auxin repress the expression of the KNOX gene that inhibits GA biosynthesis. Beige colour represents nascent primordia. level of regulation of CK activity in meristems (Kurakawa et al., 2007). logmutants have also defects in controlling meristem size and phyllotaxis, as well as reduced number of floral organs. $\angle O G$ encodes a meristem-specific enzyme that catalyzes the last two steps in CK biosynthesis, ensuring then the ability to convert inactive into active forms of CKs in the right place and at the right time.

The CK pathway is not only a target for the WUS/CL Vpathway, but also as a link with the STMBP network (Fig. 3). Inducible expression of $S T M$ results in increased mRNA levels of several CK-biosynthetic genes, IPT5 and IPT7, and in the enhancement of CK signaling and $A R R 5$ induction (Jasinski et al., 2005). In fact, mutations that compromise CK perception, for example the woodenleg (wol) allele of the CK receptor CRE1 (Inoue et al., 2001), enhance the phenotype of weak stm alleles. Consequently, the combined activity of several meristem maintenance and identity genes ensures high CK activity, which is beneficial for proper meristem function. Moreover, the negative effect of ARR7 activity upon WUS expression (Leibfried et al., 2005) provides increased robustness to these regulatory networks.

CKs are not the only hormones regulating meristem activity. Contrary to the positive effect of CKs, the growth promoting GAs are actively excluded from the SAM in several species, suggesting that their activity could be detrimental for meristem function. For instance, conditional over-expression of the tobacco KNOTTED1-like homeobox gene NTH15 in transgenic tobacco plants specifically represses in the SAM the expression of a gene encoding a GA 20-oxidase, a key enzyme in the GA biosynthetic pathway (Sakamoto et al., 2001). Similarly, over-expression of maize KNOTTED1 or Arabidopsis KNAT1 (another name for BP) in Arabidopsis also results in decreased expression of the GA200x1 gene (Hay et al., 2002). This functional relationship is confirmed by the fact that mutations that constitutively activate the GApathway, such as spindly (spy), enhance the phenotype of weak stmalleles, similar to the effect of reducing CK perception. Neither spy mutants nor plants deficient in CKs have noticeable defects in meristem function; however, combination of spymutation in a background with reduced CKs resulted in strong defects in meristems, indicating that a "high regime of CKs and a low regime of GAs" is critical for proper SAM function (Jasinski et al., 2005). Further evidence that supports this model is the observation that CKs promote GA deactivation at the base of the SAM, to avoid inflow of active GAs from leaves. This environment may facilitate cell division at the SAM through CK activity and reduced cell elongation through low GA regime (Jasinski et al., 2005).

Interestingly, this regulatory network involving GAs and KNOX genes also works in leaves (Hay et al., 2002). In Arabidopsis, which has simple leaves, BP activity is excluded from leaf primordia and confined to the SAM by the activity of AS1, therefore creating a high GA environment that promotes leaf identity. However, the dissected shape of tomato leaves is due to the functioning of a similar module both in the SAM and in the leaf, thus creating a low GA regime at both locations. Surprisingly, auxin pops up in this scenario, because it has been recently shown that this hormone is necessary, together with AS1, to repress the expression of the KNOX gene $B P$ to promote the development of simple leaves in Arabidopsis (Fig. 3) (Hay et al., 2006). This provides evidence for a dual role of auxin both in marking sites where new organ primordia will arise (see below) 
A
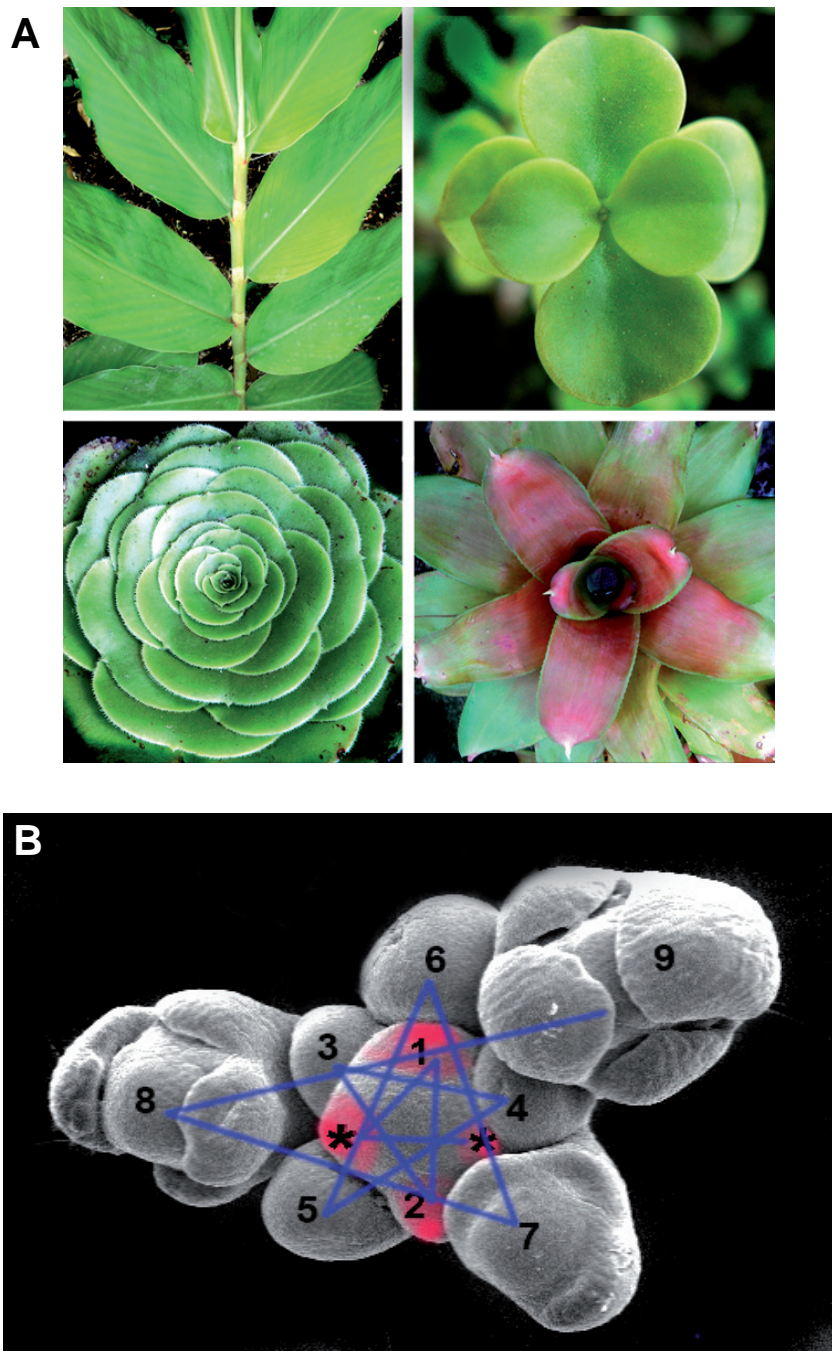

C
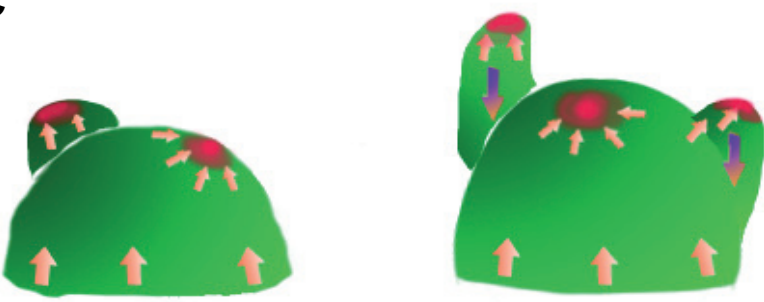

Fig. 4. Determination of organ distribution along an indeterminate inflorescence. (A) Examples of phyllotactic patterns in plants. (B) Spiral phyllotactic arrangement of the Arabidopsis inflorescence. Positions of floral primordia are numbered and incipient primordia noted with asterisks. Blue lines link positions of consecutive primordia and red spots note the positions of auxin maxima in the meristem. (C) Model for the control of phyllotaxis by auxin. In the meristems, auxin is transported towards the apex through the epidermal layer, where growing primordia act as auxin sinks. Positions in the periphery of the meristem at a certain distance of a growing primordia are able to accumulate auxin up to a certain threshold, which causes PIN1 induction and further auxin buildup (red). New primordia inception takes place at these auxin maxima, while older primordia start to pump auxin back to the stem, reducing their capacity to act as auxin sinks. and also in maintaining their identity.

The involvement of hormone pathways adds a remarkable level of complexity to the regulation of meristem activity. The basic WUS/CL V and STM BP regulatory networks are rather simple, primarily based on a negative feedback loops and in tissue specific expression of their components. Recruitment of CKs, GAs, and auxin pathways implies more nodes for plastic regulation, i.e. hormone biosynthesis, transport, and signaling, that may guarantee proper buffering of the essential meristem activity as well as connection to endogenous signals and also to environmental cues.

\section{Establishment of repetitive patterns in morphogen- esis: auxin and phyllotaxis}

The asymmetrical distribution of auxin along the main axis of the plant and in other local territories is not only used to define apical-basal polarity or the formation of meristems in the embryo. PAT is also a key determinant of plant architecture because it determaines the position at which new organs arise during postembryonic development. Aerial organs, such as leaves and flowers, are arranged regularly around the plant stem following characteristic phyllotactic patterns (Fig. 4A,B) (Reinhardt, 2005). Again, several mutants affected in auxin synthesis, transport or perception show defects in phyllotaxis, pointing to a role for auxin in organ formation and regular arrangement (Bennett et al., 1995, Gälweiler et al., 1998, Okada et al., 1991). In fact, several pieces of evidence demonstrate that auxin is the factor establishing the position at which new organs arise in the periphery of the shoot apical meristem: auxin concentration maxima coincide with sites of new primordia formation (Heisler et al., 2005); inhibition of auxin transport, both chemically or genetically, blocks organogenesis producing naked meristems; then, microapplication of auxin to these organless meristems induces primordia growth (Reinhardt et al., 2000).

Recent findings on auxin dynamics in the shoot apical meristem have made clear the role of PIN proteins in this process. PIN1-dependent PAT directs auxin into the meristem; when auxin concentration reaches a certain threshold, PIN1 reorients to pump more auxin to the site of organ initiation and thus inducing organ formation. Pumping auxin to sites of organ initiation also causes depletion in neighboring cells, inhibiting in those surroundings primordial emergence. Only at a certain distance of the incipient primordium, auxin is able to reach threshold concentrations again to induce PIN repolarization and create a new peak that triggers organ emergence (Fig. 4C) (Reinhardt et al., 2003). Computer models have been generated that nicely recreate phyllotactic patterns using only experimental parameters based on the assumption of the autoregulatory loop between auxin, PIN1 expression and polar localization of PIN1 (Jonsson et al., 2006, Smith et al., 2006).

\section{Creation of identity boundaries: auxin and patterning of the gynoecium}

Beyond the main axis of the plant, polar distribution of auxin also generates local morphogenetic gradients in several organs, that specify positional information and, accordingly, cell fate. One example is the patterning of the gynoecium. The female reproduc- 

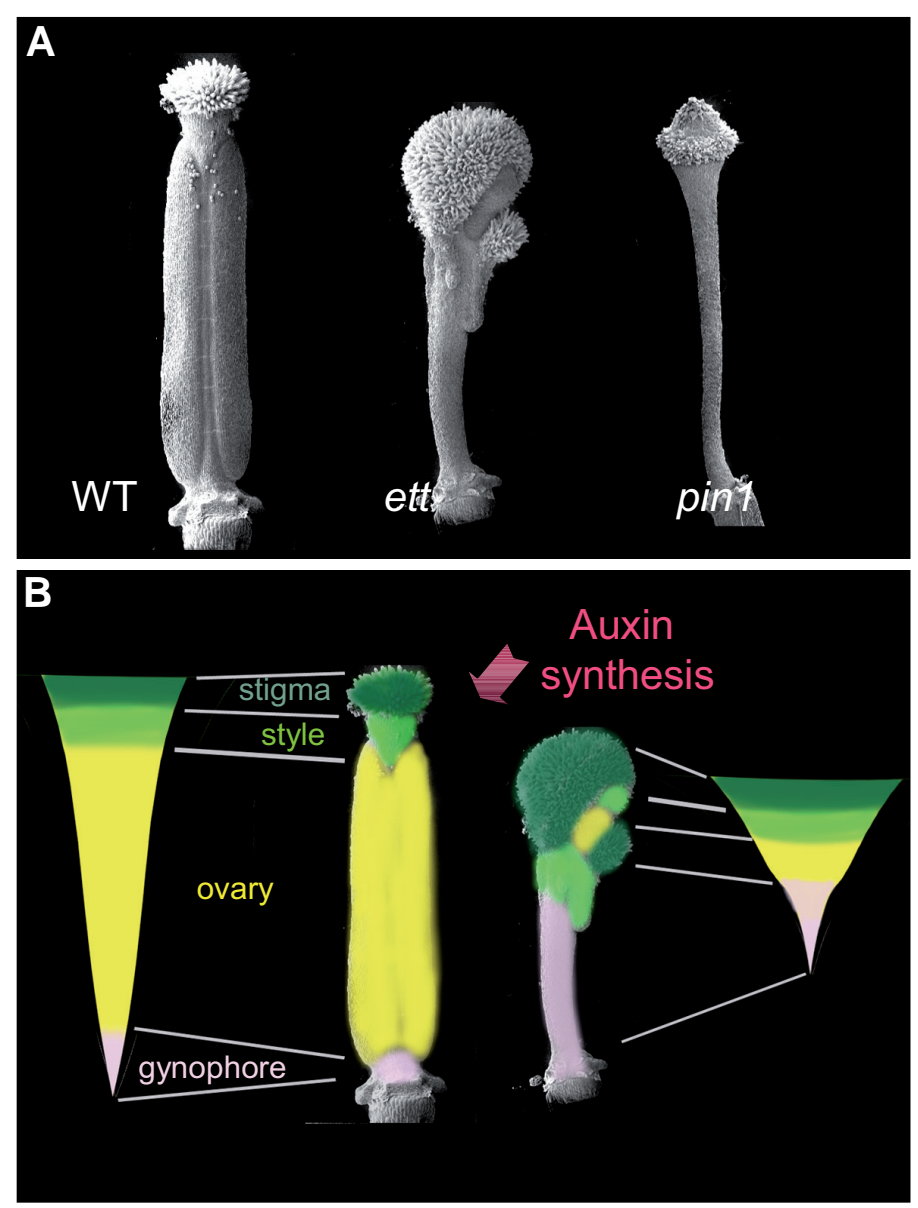

Fig. 5. Patterning of the Arabidopsis gynoecium. (A) Scanning electron micrographs of mature gynoecia of Arabidopsis wild type, ettin or pin1 mutant plants. (B) Model for gynoecium patterning based on the auxin gradient hypothesis. Auxin levels would be highest (dark green) in apical regions, directing stigma formation; high levels (light green) would promote style development; intermediate (yellow), the ovary; and low levels (white) would allow gynophore formation. Altering the shape of this gradient, for example by chemically inhibiting polar auxin transport or genetically interfering with auxin signaling pathways as in ettin mutants, would have a dramatic effect on the distribution and relative proportions of the gynoecial tissues (right panels).

tive organ of the flower, is a major evolutionary acquisition of the angiosperms, which after ovule fertilization grows into a fruit to protect the developing seeds and subsequently provide a mechanism for successful seed dispersal. Gynoecia in most angiosperms are complex structures that develop specialized tissues such as the stigma, in charge of pollen reception, the style, which allows pollen tube transmission, and the ovary, which gives shelter for seed development and maturation, and frequently undergoes further differentation to provide mechanisms for seed dispersal (Balanza et al., 2006). The patterning of the gynoecium into these different compartments usually follows apical-basal, and transversal axes of symmetry. In Arabidopsis, gynoecium patterning has been intensively studied during the past few years, when several mutations disrupting normal patterning along these axes where identified. As in the cases shown above, auxin is also linked to gynoecium patterning, specially along the apical-basal axis.
For instance, mutations in ETTIN, a member of the ARF family, cause a dramatic alteration on the relative proportions of stigma, style and ovary tissues (Fig. 5A) (Sessions etal., 1997). Mutations affecting PIN1, the auxin efflux carrier, or chemical inhibition of auxin transport leads to related patterning defects. Based on this and additional genetic evidence, it was proposed that the apicalbasal patterning is dependent on an auxin gradient spanning the gynoecial primordium (Nemhauser et al., 2000). Auxin would be synthesized at the apical end of the gynoecium and transported to the bottom, forming a decreasing gradient. According to this hypothesis, high levels of auxin would induce style and stigma differentiation, intermediate levels would form the ovary, and low levels the basal stalk where the ovary sits (Fig. 5B). Inhibition of auxin transport in the gynoecium would lead to auxin accumulation in source tissues, hypothesized to be the apical parts, and depletion in the basal regions. This model has received additional support by the recent finding that several YUCCA genes, which encode key enzymes in the auxin biosynthetic pathway, are active in the apical gynoecium, the predicted auxin source for this gradient, and, when mutated, severely disrupt apical-basal patterning (Cheng et al., 2006). However, the actual gradient, that is, the precise pattern of auxin accumulation is not fully resolved, and the molecular mechanisms that translate the gradient into tissue differentiation are far from understood.

\section{A morphogenetic switch triggered by light and hor- mones}

So far we have reviewed the roles of several hormones as patterning signals and key components of differentiation mechanisms. An additional instructive role is the determination of the appropriate morphogenetic program. One of the best examples is the choice of the most appropriate developmental plan in the early stages of postembryonic growth. Right after germination, seedlings follow one of two alternative developmental programs depending on the presence of light (Fankhauser and Chory, 1997). In darkness, seedlings undergo skotomorphogenesis, which is characterized by etiolated, long hypocotyls, and the maintenance of an apical hook with folded cotyledons. This program is designed to favor emergence of seedlings from the soil and through a first layer of canopy. When seedlings reach the light, their developmental plan is switched to photomorphogenesis, which implies unfoldig of the apical hook, opening and expansion of the cotyledons, cesation of hypocotyl elongation, and induction of the expression of genes mostly involved in protection from oxidative damage and the use of light as an energy source (Neff et al., 2000).

It is generally admitted that photomorphogenesis is a default program which is actively repressed in darkness. This repression is mainly achieved in Arabidopsis through the activity of COP1, an E3 ubiquitin ligase which acts in the nucleus of dark-grown plants to inactivate a host of transcription factors required for lightdependent gene expression (Huq, 2006, Lorrain et al., 2006). Among these transcription factors are HY5 and HYH (two bZIP proteins) (Holm et al., 2002), HFR1 (a bHLH protein) (Duek and Fankhauser, 2003) and LAF1 (a myb protein) (Ballesteros et al., 2001). Besides, during growth in darkness, other transcription factors such as the PIF proteins, seem to exert a positive effect on skotomorphogenesis, for instance by inducing cell growth and 
repressing chlorophyll accumulation (Duek and Fankhauser, 2005).

At least two hormone classes have been unequivocally linked to the repression of photomorphogenesis and the promotion of skotomorphogenesis (Alabadí and Blázquez, 2008). Brassinosteroid (BR)-deficient mutants of several species display a dramatic de-etiolated phenotype in darkness (Fig. 6), including high level of expression of many genes involved in photomorphogenesis (Li et al., 1996, Szekeres et al., 1996). The same is true for GA-deficient mutants in Arabidopsis (Fig. 6), which indicates that hormonal control of the switch between photomorphogenesis and skotomorphogenesis has been conserved through evolution (Achard et al., 2007, Alabadi et al., 2004, Vriezen et al., 2004). One interesting exception is Pisum sativum, in which photomorphogenesis is repressed by GAs, but not by BR (Alabadi et al., 2004, Symons and Reid, 2003, Symons et al., 2002).

Exogenous supply of GAs or BR to Arabidopsis cop 1 mutants does not rescue their de-etiolated phenotype in darkness, indicating that these hormones require the activity of COP1 to repress photomorphogenesis, at least to a large extent. A likely mechanism involves the regulation by GAs (and possibly BR) of the levels or activity of HY5 and the other transcription factors (Alabadi etal., 2008). In any case, GAs and BR seem to represent a regulatory module that is integral to the switch between skotoand photomorphogenesis. The physiological relevance of this regulation is partly supported by the observation that GA concentration, and the expression of GA-biosynthesis genes drop dramatically in pea and in Arabidopsis, respectively, when darkgrown seedlings are transferred to light (Achard et al., 2007, Alabadi et al., 2008, Garcia-Martinez and Gil, 2001, Reid et al., 2002). This inhibition of GA biosynthesis by light during deetiolation would have the purpose of deactivating the repression imposed by the hormones in darkness, and clearly must follow a mechanism different to the induction of GA biosynthesis during seed germination. The connection between light and BR is also complex, and involves regulation by light of BR biosynthesis (Bancos et al., 2006), and modulation of light sensitivity by variations in BR concentration (Neff et al., 1999).

\section{Senesce or develop: hormonal regulation of fruit set}

A last example that illustrates the participation of hormones in the switch between alternative developmental programs is the decision that culminates reproductive development in plants: the formation -or not- of a fruit. Fruit set can be defined as the activation of the developmental program that converts a pistil into a developing fruit. It is generally assumed that the pistil is genetically designed to construct a fruit, but in fact the default pathway followed by the gynoecium ends up in a senescence process that causes self-destruction. Only if the pistil receives an external signal is this programmed senescence repressed and substituted by the alternative program of fruit development.

Apparently the instructive signal that induces fruit set is thus originated by an event of fertilization of the ovules, but the mere existence of seedless (parthenocarpic) fruits indicates that fertilization is not an absolute requirement. Indeed, application of certain hormones, like GAs and auxin can induce the formation of fruits in emasculated flowers (Fig. 7) (Gustafson, 1936), or after early abortion of developing seeds (Eeuwens and Schwabe,
1975). These observations were initially taken as an indication that these hormones might conform the initial instructive signal that promotes the fruit development program in physiological conditions (Garcia-Martinez and Carbonell, 1980, Gustafson, 1936, Nitsch, 1950, Ozga and Reinecke, 1999, Vivian-Smith and Koltunow, 1999), and current work is based on the hypothesis that the different hormones play their roles in a mostly sequencial way (Gillaspy et al., 1993). As we will see below, the first signal in the sequence of events seems to be auxin, followed by GAs. In certain species, a minor participation of CKs and also of abscisic acid, as a counterpart of GAs, has been reported (García-Martínez and Carbonell, 1980).

The evidence for the instructive role of auxin and GAs in triggering the fruit developmental program is found in at least three concurrent observations: (i) the correlation between variations in hormone concentration and the initiation of fruit development; (ii) the enhanced ability of certain parthenocarpic mutants to synthesize hormones; and (iii) the parthenocarpy induced by the manipulation of hormone signaling.

The presence of auxin in developing ovaries, as a patterning morphogen, has already been discussed above. However, more relevant to this role in the initiation of fruit development is the observation that, in Arabidopsis, no auxin accumulation or signaling is observed in ovules before anthesis, or afterwards if no fertilization occurs. In contrast, immediately after fertilization, the developing embryo and seed show elevated auxin signaling, determined by the increased level of expression of an auxinresponsive reporter DR5-GUS in transgenic lines (Aloni et al., 2006). Remarkably, the inhibition of auxin polar transport by the

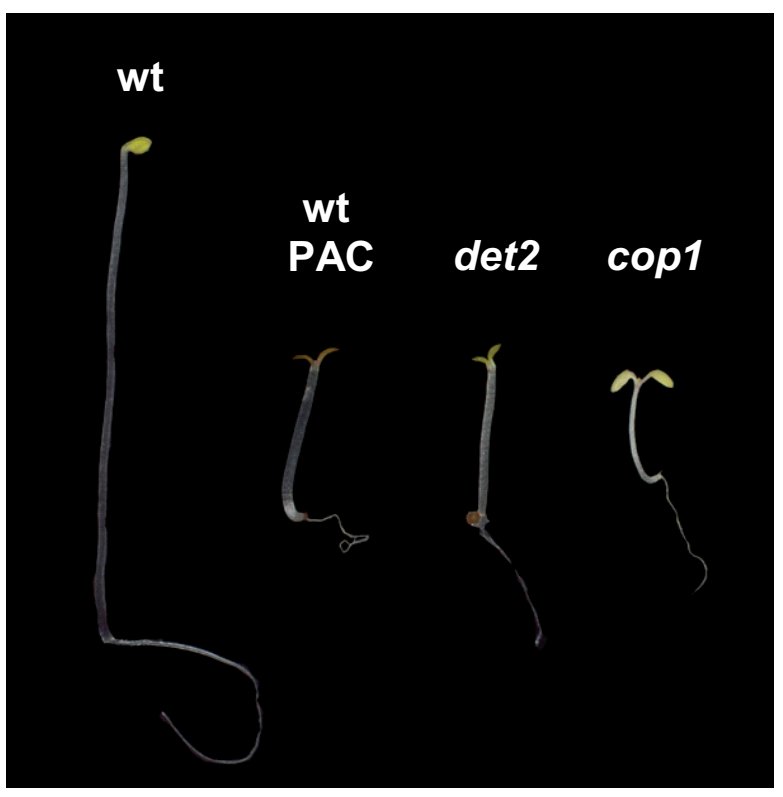

Fig. 6 Repression of photomorphogenesis by gibberellins and brassinosteroids. Seven-day-old dark grown seedlings of the wild type show an etiolated phenotype, unlike cop1 mutant seedlings, defective in the machinery that inactivates light-dependent transcription factors in darkness. Seedlings deficient in gibberellin biosynthesis (treated with 1 $\mu M$ paclobutrazol [PAC]) and det2 mutant seedlings defective in brassinosteroid biosynthesis, also display a deetiolated phenotype in darkness, with shorter hypocotyls, unfolded apical hook and open cotyledons. 

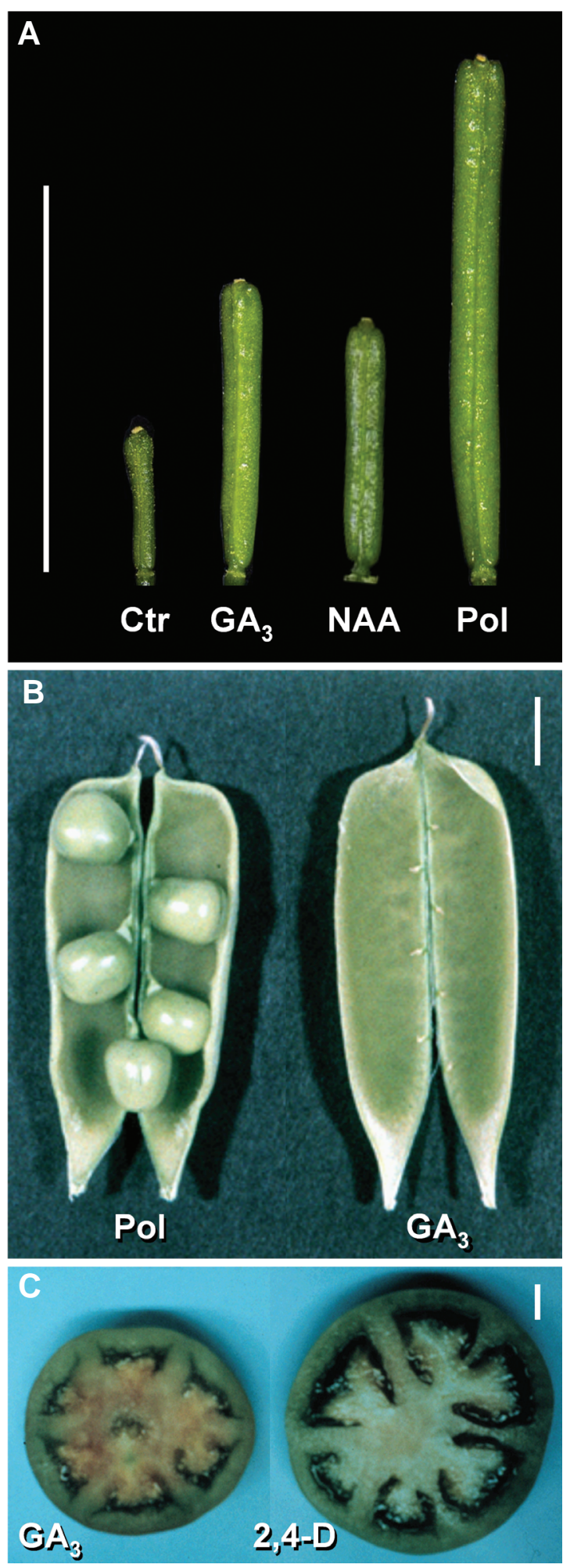

Fig. 7. Induction of fruit development by hormone applications. Parthenocarpic fruit growth can be promoted by gibberellins and auxins in different plant species: Arabidopsis (A), pea (B) and tomato (C). The size bar represents $10 \mathrm{~mm}$ length. Ctr, unpollinated control; Pol, pollinated; $G A_{3}$ gibberellic acid; NAA, 1-naphtaleneacetic acid (auxin); 2,4-D, 2,4-dichlorophenoxyacetic acid (auxin). application of morphactin or N-1-naphthylphthalamic acid (NPA), can also induce parthenocarpic development in cucumber (Beyer and Quebedeaux, 1974, Robinson et al., 1971). A simple explanation could be that these inhibitors probably block the outward flow of auxin from the ovary, resulting in auxin accumulation within the ovule, sufficient to trigger fruit-set in absence of fertilization.

Strong experimental evidence indicates that GAs are also necessary for proper fruit-set and development in different plant species. For instance, the expression in pea of a GA200x gene (involved in GA biosynthesis) increases after fertilization, not only in the pods (where GAs would be necessary for the cell expansion observed during fruit growth), but also in the fertilized ovules, which is more indicative of an instructive role (Garcia-Martinez et al., 1997). Moreover, mechanical elimination of pea ovules soon after fertilization prevents fruit differentiation (Garcia-Martinez et al., 1991b), and this defect is intimately associated with the loss of GA synthesis in seeds (Garcia-Martinez et al., 1997, GarciaMartinez et al., 1991a). In seeded varieties of citrus, pollination increases $\mathrm{GA}$ concentration, including the bioactive $\mathrm{GA}_{1}$ and $\mathrm{GA}_{20}$ molecules (Ben-Cheikh et al., 1997). Finally, in Arabidopsis, ectopic expression of the pea GA2ox2 gene, which encodes a protein involved in inactivation of the active GAs, causes seed abortion and shorter siliques (Singh et al., 2002).

Given that both auxin and GAs are required to specify the differentiation of the ovary into a fruit, what is the hierarchy between these two hormones? The most likely answer is that GA accumulation is triggered by auxin (Fig. 8). For instance, application of the auxin 4-chloroindole-3-acetic acid (4-CI-IAA) to pea ovaries induces the expression of genes involved in GA biosynthesis and accumulation of GAs (Ozga and Reinecke, 1999, Ozga et al., 2003, Van Huizen et al., 1997, van Huizen et al., 1995), in a mechanism that seems not to be specific for fruit development, but exerted at different stages and tissues (Frigerio et al., 2006).

As stated above, supporting evidence for an instructive role of auxin and GAs in fruit set is the increased hormonal content in parthenocarpic plants. For instance, levels of 13-hydroxy-GAs are higher in the parthenocarpic citrus varietiy Satsuma than in the non-parthenocarpic self-incompatible Clementine, which suggests that endogenous GA concentration in developing ovaries is the limiting factor controlling parthenocarpic development (Talon et al., 1992). Similarly. parthenocarpic pat2 and pat3/pat4 mutants of tomato show enhanced expression of GA biosynthetic genes and increased levels of active GAs (Fos et al., 2000, Fos et al., 2001).

Finally, genetic evidence also indicates that auxin is the primary signal that triggers fruit differentiation. Loss-of-function of the tomato IAA9 gene, encoding a nuclear-localized Aux/IAA protein, results in plants with parthenocarpic fruits, suggesting thatn $/ A A 9$ inhibits premature fruit growth or growth in the absence of fertilization (Wang et al., 2005). In addition, loss of $A R F 8$ function in the Arabidopsis mutants fwf (also named arf8-4) also results in parthenocarpic fruit development (Goetz et al., 2006, Vivian-Smith et al., 2001), which indicates that the participation of ARF and Aux/IAA-related proteins in the induction of fruit set is a widespread mechanism in both dry and fleshy fruits. From a biotechnological point of view, the discovery of auxin as the signal triggering fruit development has been successfully exploited in several species. Indeed, parthenocarpy has been achieved by genetic engineering, through the forced expression of an auxin 


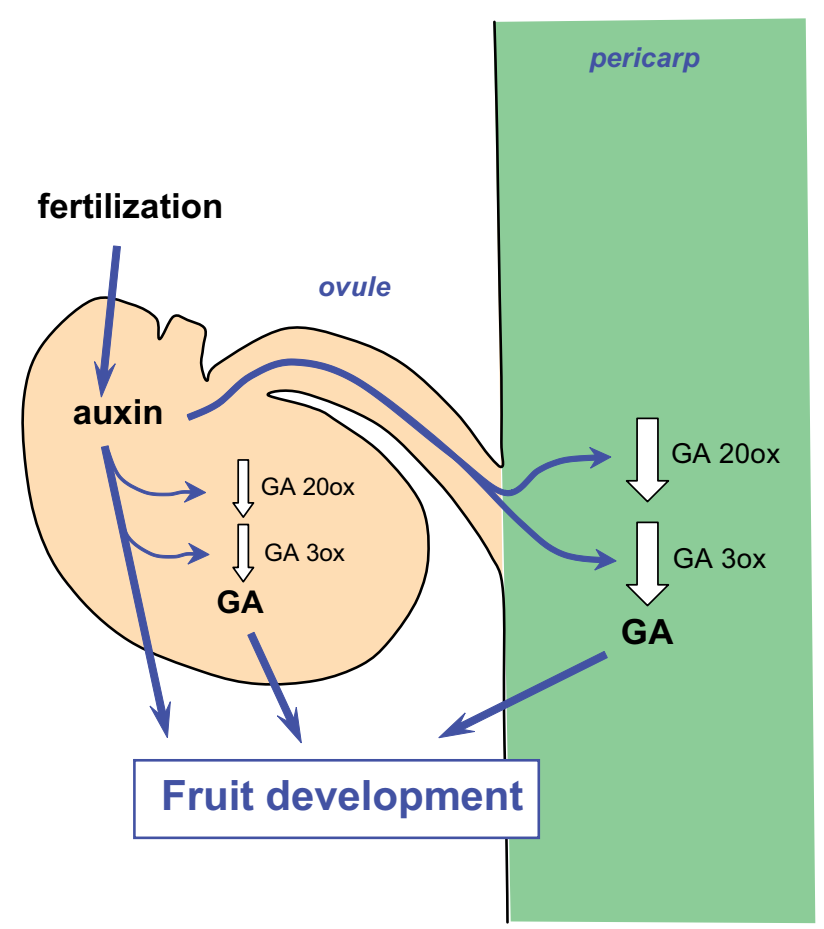

Fig. 8. A model for fruit set. Fertilization of ovules (beige colour) triggers a local increase in auxin concentration which results in the activation of gibberellin (GA) biosynthesis both in the fertilized ovules and in the rest of the ovary (green), which will develop as a fruit thanks to the concerted action of auxin and GAs in the different tissues. GA 20x and GA 3ox are enzymes involved in GA biosynthesis, and the genes encoding these activities are upregulated by auxin.

biosynthesis gene, such as iaaM from Pseudomonas syringae, under the control of the promoter of the placenta- and ovulespecific gene DefH9from Antirrhinum majusin tobacco, eggplant, tomato, raspberry, strawberry, cucumber and grape (Acciarri et al., 2002, Costantini et al., 2007, Ficcadenti et al., 1999, Mezzetti et al., 2004, Mezzetti et al., 2002, Pandolfini et al., 2002, Rotino et al., 1997, Yin et al., 2006).

\section{Is there something that makes them so special?}

There are several examples of the independent invention of equivalent developmental mechanisms in plants and animals (Meyerowitz, 1999). The recruitment of hormones to instruct certain developmental processes in plants is an alternative solution to the common problems posed in development, of establishing boundaries, informational gradients, or regulatory switches. It is very likely that hormones probably arose as a biological need to integrate the overall development during the diversification of land plants (Kendrick and Crane, 1997). Although very little is known about the origin and evolution of the signaling pathways for most plant hormones, we can speculate about auxin in particular. As we have discussed, auxin appears to be an almost universal factor common for most key patterning events during plant development. But, has auxin taken this central role fortuitously during evolution, or has it been selected for a good reason? As for most photo-finish scenarios, we can only speculate on this question looking at extant plants. One possibility is that the chemical properties of IAA could make auxin a particularly good signaling molecule. IAA is a small organic molecule with an indol group, soluble in aqueous media and also able to cross membranes (Woodward and Bartel, 2005). Auxins (and several other hormones) are already present in unicellular algae where they have been postulated to act as pheromones. From there to multicellular organisms, transport systems had to evolve, and then, similarities with tryptophan could have been the base for an ancestral affinity for aminoacid transporters. In multicellular organisms they could have been recruited to directional growth responses and evidences have been provided that their role in branching and polarized growth are already present in mosses (Cooke et al., 2002).

All land plants have the same basic metabolic and transport mechanisms, with increasing sophistication correlating with position in the phylogenetic tree. Some IAA responses, such as the asymmetric IAA distribution in tropic organs or the apical dominance directed by auxin flow from the apex, appeared early in evolution. Auxin was also early recruited to direct vascular and root development (Cooke et al., 2002, Decker et al., 2006, Sakakibara et al., 2003). It is a central idea in recent evo-devo studies that evolution of body plans could come from duplication and subsequent diversification of developmental genes or gene networks (Freeling and Thomas, 2006, Prince, 2002). In higher plants, there is a good correlation between increasing complexity of body plans and the gene number for ARF/PIN/IAA genes, supporting this central role of auxin signaling in shaping the plants. This redundancy seems to be a central theme in plant hormone signaling (Casal et al., 2004), and may justify, at least in part, the enhanced plasticity and robustness of post-embryonic plant development, compared to animals.

\section{Acknowledgments}

We thank F. Madueño (IBMCP, Valencia) for critical reading of the manuscript. Research in the authors' laboratories is funded by grants from the Spanish Ministry of Education and Science (BIO2004-02357, BIO2005-07156-C02-01, BIO2006-10358 and from the Generalitat Valenciana.

\section{References}

ACCIARRI, N., REstaino, F., VITELLI, G., PERRONE, D., ZOTTINI, M., PANDOLFINI, T., SPENA, A. and ROTINO, G. (2002). Genetically modified parthenocarpic eggplants: improved fruit productivity under both greenhouse and open field cultivation. BMC Biotechno/2: 4.

ACHARD, P., LIAO, L., JIANG, C., DESNOS, T., BARTLETT, J., FU, X. and HARBERD, N.P. (2007). DELLAs Contribute to Plant Photomorphogenesis. Plant Physiol143: 1163-72.

ALABADÍ, D. and BLÁZQUEZ, M.A. (2008) Molecular interactions between light and hormone signaling to control plant growth Plant Mol. Biol. doi: 10.1007/ s11103-008-9400-y

ALABADI, D., GALLEGO-BARTOLOME, J., GARCIA-CARCEL, L., ORLANDO, L., RUBIO, V., MARTÍNEZ, C., FRIGERIO, M., IGLESIAS-PEDRAZ, J.M., ESPINOSA, A., DENG, X.W. et al. (2008). Gibberellins modulate light signaling pathways to prevent Arabidopsis seedling de-etiolation in darkness. Plant J53: 324-335.

ALABADI, D., GIL, J., BLÁZQUEZ, M.A. and GARCIA-MARTINEZ, J.L. (2004) Gibberellins repress photomorphogenesis in darkness. Plant Physiol 134 1050-7.

ALONI, R., ALONI, E., LANGHANS, M. and ULLRICH, C.I. (2006). Role of auxin in regulating Arabidopsis flower development. Planta 223: 315-28.

ALONI, R., SCHWALM, K., LANGHANS, M. and ULLRICH, C.I. (2003). Gradual shifts in sites of free-auxin production during leaf-primordium development and 
their role in vascular differentiation and leaf morphogenesis in Arabidopsis. Planta 216: 841-53.

BALANZA, V., NAVARRETE, M., TRIGUEROS, M. and FERRANDIZ, C. (2006). Patterning the female side of Arabidopsis: the importance of hormones. J. Exp. Bot. 57: 3457-3469.

BALLESTEROS, M.L., BOLLE, C., LOIS, L.M., MOORE, J.M., VIELLE-CALZADA, J.P., GROSSNIKLAUS, U. and CHUA, N.H. (2001). LAF1, a MYB transcription activator for phytochrome A signaling. Genes Dev 15: 2613-25.

BANCOS, S., SZATMARI, A.M., CASTLE, J., KOZMA-BOGNAR, L., SHIBATA, K., YOKOTA, T., BISHOP, G.J., NAGY, F. and SZEKERES, M. (2006). Diurnal regulation of the brassinosteroid-biosynthetic CPD gene in Arabidopsis. Plant Physio/141: 299-309.

BEN-CHEIKH, W., PEREZ-BOTELLA, J., TADEO, F.R., TALON, M. and PRIMOMILLO, E. (1997). Pollination Increases Gibberellin Levels in Developing Ovaries of Seeded Varieties of Citrus. Plant Physio/114: 557-564.

BENKOVA, E., MICHNIEWICZ, M., SAUER, M., TEICHMANN, T., SEIFERTOVA, D., JURGENS, G. and FRIML, J. (2003). Local, efflux-dependent auxin gradients as a common module for plant organ formation. Cel/115: 591-602.

BENNETT, S.R.M., ALVAREZ, J., BOSSINGER, G. and SMYTH, D.R. (1995). Morphogenesis in pinoidmutants of Arabidopsis thaliana. The Plant Journa/8: 505-520.

BEYER, E. and QUEBEDEAUX, B. (1974). Parthenocarpy in cucumber: mechanism of action of auxin transport inhibitors. J Am Soc Hort Sci99: 385-390.

BLILOU, I., XU, J., WILDWATER, M., WILLEMSEN, V., PAPONOV, I., FRIML, J., HEIDSTRA, R., AIDA, M., PALME, K. and SCHERES, B. (2005). The PIN auxin efflux facilitator network controls growth and patterning in Arabidopsis roots. Nature 433: 39-44.

CASAL, J.J., FANKHAUSER, C., COUPLAND, G., BLAZQUEZ, M.A. (2004) Signalling for developmental plasticity. Trends Plant Sci. 9: 309-314.

CHENG, Y., DAI, X. and ZHAO, Y. (2006). Auxin biosynthesis by the YUCCA flavin monooxygenases controls the formation of floral organs and vascular tissues in Arabidopsis. Genes Dev20: 1790-9.

COOKE, T.J., POLI, D., SZTEIN, A.E. and COHEN, J.D. (2002). Evolutionary patterns in auxin action. Plant Mo/ Bio/49: 319-38.

COSTANTINI, E., LANDI, L., SILVESTRONI, O., PANDOLFINI, T., SPENA, A. and MEZZETTI, B. (2007). Auxin synthesis-encoding transgene enhances grape fecundity. Plant Physiol143: 1689-94.

DECKER, E.L., FRANK, W., SARNIGHAUSEN, E. and RESKI, R. (2006). Moss systems biology en route: phytohormones in Physcomitrella development. Plant Biol (Stuttg) 8: 397-405.

DHARMASIRI, N., DHARMASIRI, S. and ESTELLE, M. (2005a). The F-box protein TIR1 is an auxin receptor. Nature 435: 441-5.

DHARMASIRI, N., DHARMASIRI, S., WEIJERS, D., LECHNER, E., YAMADA, M., HOBBIE, L., EHRISMANN, J.S., JURGENS, G. and ESTELLE, M. (2005b). Plant development is regulated by a family of auxin receptor $\mathrm{F}$ box proteins. Dev Cel/9: 109-19.

DUEK, P.D. and FANKHAUSER, C. (2003). HFR1, a putative bHLH transcription factor, mediates both phytochrome $A$ and cryptochrome signalling. Plant $J 34$ : 827-36

DUEK, P.D. and FANKHAUSER, C. (2005). bHLH class transcription factors take centre stage in phytochrome signalling. Trends Plant Sci 10: 51-4.

EHEBAUER, M., HAYWARD, P. and ARIAS, A.M. (2006). Notch, a universal arbiter of cell fate decisions. Science 314: 1414-5.

ESMON, C.A., TINSLEY, A.G., LJUNG, K., SANDBERG, G., HEARNE, L.B. and LISCUM, E. (2006). A gradient of auxin and auxin-dependent transcription precedes tropic growth responses. Proc Nat/ Acad Sci USA 103: 236-41.

FANKHAUSER, C. and CHORY, J. (1997). Light control of plant development. Annu Rev Cell Dev Biol13: 203-29.

FICCADENTI, N., SESTILI, S., PANDOLFINI, T., CIRILLO, C., ROTINO, G. and SPENA, A. (1999). Genetic engineering of parthenocarpic fruit development in tomato. Mol Breed 5: 463-470.

FOS, M., NUEZ, F. and GARCIA-MARTINEZ, J.L. (2000). The gene pat-2, which induces natural parthenocarpy, alters the gibberellin content in unpollinated tomato ovaries. Plant Physio/122: 471-80.

FOS, M., PROANO, K., NUEZ, F. and GARCIA-MARTINEZ, J.L. (2001). Role of gibberellins in parthenocarpic fruit development induced by the genetic system pat-3/pat-4 in tomato. Physiol Plant 111: 545-550.

FREELING, M. and THOMAS, B.C. (2006). Gene-balanced duplications, like tetraploidy, provide predictable drive to increase morphological complexity. Genome Res. 16: 805-814.

FRIGERIO, M., ALABADI, D., PEREZ-GOMEZ, J., GARCIA-CARCEL, L., PHILLIPS, A.L., HEDDEN, P. and BLAZQUEZ, M.A. (2006). Transcriptional regulation of gibberellin metabolism genes by auxin signaling in Arabidopsis. Plant Physiol 142: 553-63.

FRIML, J. (2003). Auxin transport - shaping the plant. Curr Opin Plant Bio/6: 7 12

FRIML, J., BENKOVA, E., BLILOU, I., WISNIEWSKA, J., HAMANN, T., LJUNG, K. WOODY, S., SANDBERG, G., SCHERES, B., JURGENS, G. et al. (2002). AtPIN4 mediates sink-driven auxin gradients and root patterning in Arabidopsis. Cel/108: 661-73.

FRIML, J., VIETEN, A., SAUER, M., WEIJERS, D., SCHWARZ, H., HAMANN, T. OFFRINGA, R. and JURGENS, G. (2003). Efflux-dependent auxin gradients establish the apical-basal axis of Arabidopsis. Nature 426: 147-53.

GÄLWEILER, L., GUAN, C., MÜLLER, A., WISMAN, E., MENDGEN, K., YEPHREMOV, A. and PALME, K. (1998). Regulation of Polar Auxin Transport by AtPIN1 in Arabidopsis Vascular Tissue. Science 282: 2226-2230.

GARCIA-MARTINEZ, J.L. and CARBONELL, J. (1980). Fruit-set of unpollinated ovaries of Pisum sativum L. Influence of plant growth regulators. Planta 147: 451-456.

GARCIA-MARTINEZ, J.L. and GIL, J. (2001). Light Regulation of Gibberellin Biosynthesis and Mode of Action. J Plant Growth Regu/20: 354-368.

GARCIA-MARTINEZ, J.L., LOPEZ-DIAZ, I., SANCHEZ-BELTRAN, M.J., PHILLIPS, A.L., WARD, D.A., GASKIN, P. and HEDDEN, P. (1997). Isolation and transcript analysis of gibberellin 20-oxidase genes in pea and bean in relation to fruit development. Plant Mol Bio/33: 1073-84.

GARCIA-MARTINEZ, J.L., MARTI, M., SABATER, T., MALDONADO, A. and VERCHER, Y. (1991a). Development of fertilized ovules and their role in the growth of the pea pod. Physiol Plant 83: 411-416.

GARCIA-MARTINEZ, J.L., SANTES, C., CROKER, S.J. and HEDDEN, P. (1991b). Identification, quantification and distribution of gibberellins in fruits of Pisum sativum L. cv Alaska during pod development. Planta 184: 53-60.

GILLASPY, G., BEN-DAVID, H. and GRUISSEM, W. (1993). Fruits: A Developmental Perspective. Plant Cel/5: 1439-1451.

GIULINI, A., WANG, J. and JACKSON, D. (2004). Control of phyllotaxy by the cytokinin-inducible response regulator homologue ABPHYL1. Nature 430 1031-4.

GOETZ, M., VIVIAN-SMITH, A., JOHNSON, S.D. and KOLTUNOW, A.M. (2006) AUXIN RESPONSE FACTOR8 is a negative regulator of fruit initiation in Arabidopsis. Plant Cel/18: 1873-86

GRAY, W.M., KEPINSKI, S., ROUSE, D., LEYSER, O. and ESTELLE, M. (2001) Auxin regulates SCF(TIR1)-dependent degradation of AUX/IAA proteins. $\mathrm{Na}$ ture 414: 271-6.

GUSTAFSON, F. (1936). Inducement of fruit development by growth-promoting chemicals. Proc Natl Acad Sci USA 22: 628-636.

HAMANN, T., BENKOVA, E., BAURLE, I., KIENTZ, M. and JURGENS, G. (2002) The Arabidopsis BODENLOS gene encodes an auxin response protein inhibiting MONOPTEROS-mediated embryo patterning. Genes Dev 16: 1610-5.

HARDTKE, C.S. and BERLETH, T. (1998). The Arabidopsis gene MONOPTEROS encodes a transcription factor mediating embryo axis formation and vascular development. EMBO J. 17: 1405-1411.

HARDTKE, C.S., CKURSHUMOVA, W., VIDAURRE, D.P., SINGH, S.A., STAMATIOU, G., TIWARI, S.B., HAGEN, G., GUILFOYLE, T.J. and BERLETH, T. (2004). Overlapping and non-redundant functions of the Arabidopsis auxin response factors MONOPTEROS and NONPHOTOTROPIC HYPOCOTYL 4 Development 131: 1089-100.

HAY, A., BARKOULAS, M. and TSIANTIS, M. (2006). ASYMMETRIC LEAVES1 and auxin activities converge to repress BREVIPEDICELLUS expression and promote leaf development in Arabidopsis. Development 133: 3955-61.

HAY, A., KAUR, H., PHILLIPS, A., HEDDEN, P., HAKE, S. and TSIANTIS, M (2002). The gibberellin pathway mediates KNOTTED1-type homeobox function 
in plants with different body plans. Curr Bio/12: 1557-65.

HEISLER, M.G., OHNO, C., DAS, P., SIEBER, P., REDDY, G.V., LONG, J.A. and MEYEROWITZ, E.M. (2005). Patterns of auxin transport and gene expression during primordium development revealed by live imaging of the Arabidopsis inflorescence meristem. Curr Bio/ 15: 1899-911.

HOLM, M., MA, L.G., QU, L.J. and DENG, X.W. (2002). Two interacting bZIP proteins are direct targets of COP1-mediated control of light-dependent gene expression in Arabidopsis. Genes Dev 16: 1247-59.

HUQ, E. (2006). Degradation of negative regulators: a common theme in hormone and light signaling networks? Trends Plant Sci11: 4-7.

INOUE, T., HIGUCHI, M., HASHIMOTO, Y., SEKI, M., KOBAYASHI, M., KATO, T., TABATA, S., SHINOZAKI, K. and KAKIMOTO, T. (2001). Identification of CRE1 as a cytokinin receptor from Arabidopsis. Nature 409: 1060-3.

JASINSKI, S., PIAZZA, P., CRAFT, J., HAY, A., WOOLLEY, L., RIEU, I., PHILLIPS, A., HEDDEN, P. and TSIANTIS, M. (2005). KNOX action in Arabidopsis is mediated by coordinate regulation of cytokinin and gibberellin activities. Curr Bio/15: 1560-5.

JONSSON, H., HEISLER, M.G., SHAPIRO, B.E., MEYEROWITZ, E.M. and MJOLSNESS, E. (2006). An auxin-driven polarized transport model for phyllotaxis.nProc Natl Acad Sci USA 103: 1633-8.

KENDRICK, R.E. and CRANE, P. (1997). The origin and early evolution of plants on land. Nature 389: 33-39.

KEPINSKI, S. and LEYSER, O. (2005). The Arabidopsis F-box protein TIR1 is an auxin receptor. Nature 435: 446-51.

KIM, J., HARTER, K. and THEOLOGIS, A. (1997). Protein-protein interactions among the Aux/IAA proteins. Proc Nat/ Acad Sci USA 94: 11786-91.

KURAKAWA, T., UEDA, N., MAEKAWA, M., KOBAYASHI, K., KOJIMA, M., NAGATO, Y., SAKAKIBARA, H. and KYOZUKA, J. (2007). Direct control of shoot meristem activity by a cytokinin-activating enzyme. Nature 445: 652-5.

LEIBFRIED, A., TO, J.P., BUSCH, W., STEHLING, S., KEHLE, A., DEMAR, M., KIEBER, J.J. and LOHMANN, J.U. (2005). WUSCHEL controls meristem function by direct regulation of cytokinin-inducible response regulators. Nature 438: $1172-5$

LI, J., NAGPAL, P., VITART, V., MCMORRIS, T.C. and CHORY, J. (1996). A role for brassinosteroids in light-dependent development of Arabidopsis. Science 272: 398-401.

LISCUM, E. and REED, J.W. (2002). Genetics of Aux/IAA and ARF action in plant growth and development. Plant Mol Bio/49: 387-400.

LORRAIN, S., GENOUD, T. and FANKHAUSER, C. (2006). Let there be light in the nucleus! Curr Opin Plant Bio/9: 509-14.

MEYEROWITZ, E.M. (1999). Plants, animals and the logic of development. Trends Cell Bio/9: M65-8.

MEZZETTI, B., LANDI, L., PANDOLFINI, T. and SPENA, A. (2004). The defH9iaaM auxin-synthesizing gene increases plant fecundity and fruit production in strawberry and raspberry. BMC Biotechno/4: 4.

MEZZETTI, B., PANDOLFINI, T., NAVACCHI, O. and LANDI, L. (2002). Genetic transformation of Vitis vinifera via organogenesis. BMC Biotechno/2: 18.

NEFF, M.M., FANKHAUSER, C. and CHORY, J. (2000). Light: an indicator of time and place. Genes Dev 14: 257-71.

NEFF, M.M., NGUYEN, S.M., MALANCHARUVIL, E.J., FUJIOKA, S., NOGUCHI, T., SETO, H., TSUBUKI, M., HONDA, T., TAKATSUTO, S., YOSHIDA, S. et al. (1999). BAS1: A gene regulating brassinosteroid levels and light responsiveness in Arabidopsis. Proc Natl Acad Sci USA 96: 15316-23.

NEMHAUSER, J., FELDMAN, L. and ZAMBRYSKI, P. (2000). Auxin and ETTIN in Arabidopsis gynoecium morphogenesis. Development 127: 3877-3888.

NITSCH, J. (1950). Growth and morphogenesis of the strawberry as related to auxin. $A m J$ Bot 37: 211-215.

OKADA, K., UEDA, J., KOMAKI, M.K., BELL, C.J. and SHIMURA, Y. (1991). Requirement of the auxin polar transport system in early stages of Arabidopsis floral bu formation. Plant Cel/3: 677-684.

OKUSHIMA, Y., OVERVOORDE, P.J., ARIMA, K., ALONSO, J.M., CHAN, A., CHANG, C., ECKER, J.R., HUGHES, B., LUI, A., NGUYEN, D. et al. (2005). Functional genomic analysis of the AUXIN RESPONSE FACTOR gene family members in Arabidopsis thaliana: unique and overlapping functions of ARF7 and ARF19. Plant Cel/17: 444-63.
OZGA, J.A. and REINECKE, D. (1999). Interaction of 4-chloroindole-3-acetic acid and gibberellins in early pea fruit development. Plant Growth Reg 27: 33-38.

OZGA, J.A., YU, J. and REINECKE, D.M. (2003). Pollination-, development-, and auxin-specific regulation of gibberellin 3beta-hydroxylase gene expression in pea fruit and seeds. Plant Physio/131: 1137-46.

PANDOLFINI, T., ROTINO, G.L., CAMERINI, S., DEFEZ, R. and SPENA, A. (2002). Optimisation of transgene action at the post-transcriptional level: high quality parthenocarpic fruits in industrial tomatoes. BMC Biotechno/2: 1.

PRINCE, V.E. (2002). The Hox Paradox: More Complex(es) Than Imagined. Dev Bio/249: 1-15.

RAFTERY, L.A. and SUTHERLAND, D.J. (2003). Gradients and thresholds: BMP response gradients unveiled in Drosophila embryos. Trends Genet 19: 701-8.

RAMOS, J.A., ZENSER, N., LEYSER, O. and CALLIS, J. (2001). Rapid degradation of auxin/indoleacetic acid proteins requires conserved amino acids of domain II and is proteasome dependent. Plant Ce//13: 2349-60.

REID, J.B., BOTWRIGHT, N.A., SMITH, J.J., O'NEILL, D.P. and KERCKHOFFS L.H. (2002). Control of gibberellin levels and gene expression during deetiolation in pea. Plant Physio/128: 734-41.

REINHARDT, D. (2005). Regulation of phyllotaxis. Int J Dev Bio/49: 539-46.

REINHARDT, D., MANDEL, T. and KUHLEMEIER, C. (2000). Auxin regulates the initiation and radial position of plant lateral organs. Plant Cel/12: 507-18.

REINHARDT, D., PESCE, E.R., STIEGER, P., MANDEL, T., BALTENSPERGER, K., BENNETT, M., TRAAS, J., FRIML, J. and KUHLEMEIER, C. (2003). Regulation of phyllotaxis by polar auxin transport. Nature 426: 255-60.

ROBINSON, R.W., CANTLIFFE, D.J. and SHANNON, S. (1971). Morphactininduced parthenocarpy in the cucumber. Science 171: 1251-1252.

ROTINO, G.L., PERRI, E., ZOTTINI, M., SOMMER, H. and SPENA, A. (1997). Genetic engineering of parthenocarpic plants. Nat Biotechno/15: 1398-401.

RUEGGER, M., DEWEY, E., GRAY, W.M., HOBBIE, L., TURNER, J. and ESTELLE, M. (1998). The TIR1 protein of Arabidopsis functions in auxin response and is related to human SKP2 and yeast grr1p. Genes Dev 12: 198-207.

SABATINI, S., BEIS, D., WOLKENFELT, H., MURFETT, J., GUILFOYLE, T. MALAMY, J., BENFEY, P., LEYSER, O., BECHTOLD, N., WEISBEEK, P. et al. (1999). An Auxin-Dependent Distal Organizer of Pattern and Polarity in the Arabidopsis Root. Cel/99: 463-472.

SAKAKIBARA, K., NISHIYAMA, T., SUMIKAWA, N., KOFUJI, R., MURATA, T. and HASEBE, M. (2003). Involvement of auxin and a homeodomain-leucine zipper I gene in rhizoid development of the moss Physcomitrella patens. Development 130: $4835-4846$

SAKAMOTO, T., KAMIYA, N., UEGUCHI-TANAKA, M., IWAHORI, S. and MATSUOKA, M. (2001). KNOX homeodomain protein directly suppresses the expression of a gibberellin biosynthetic gene in the tobacco shoot apical meristem. Genes Dev 15: 581-90.

SAUER, M., BALLA, J., LUSCHNIG, C., WISNIEWSKA, J., REINOHL, V., FRIML, $\mathrm{J}$. and BENKOVA, E. (2006). Canalization of auxin flow by Aux/IAA-ARFdependent feedback regulation of PIN polarity. Genes Dev 20: 2902-11.

SESSIONS, A., NEMHAUSER, J., MCCOLL, A., ROE, J., FELDMANN, K. and ZAMBRYSKI, P. (1997). ETTIN patterns the Arabidopsis floral meristem and reproductive organs. Development 124: 4481-4491.

SINGH, D.P., JERMAKOW, A.M. and SWAIN, S.M. (2002). Gibberellins are required for seed development and pollen tube growth in Arabidopsis. Plant Cell 14: 3133-47

SMITH, R.S., GUYOMARC'H, S., MANDEL, T., REINHARDT, D., KUHLEMEIER, C. and PRUSINKIEWICZ, P. (2006). A plausible model of phyllotaxis. Proc Nat/ Acad Sci USA 103: 1301-6.

SWARUP, R., FRIML, J., MARCHANT, A., LJUNG, K., SANDBERG, G., PALME, K. and BENNETT, M. (2001). Localization of the auxin permease AUX1 suggests two functionally distinct hormone transport pathways operate in the Arabidopsis root apex. Genes Dev 15: 2648-53.

SYMONS, G.M. and REID, J.B. (2003). Hormone levels and response during deetiolation in pea. Planta 216: 422-31.

SYMONS, G.M., SCHULTZ, L., KERCKHOFFS, L.H., DAVIES, N.W., GREGORY, D. and REID, J.B. (2002). Uncoupling brassinosteroid levels and de-etiolation in pea. Physiol Plant 115: 311-319.

SZEKERES, M., NEMETH, K., KONCZ-KALMAN, Z., MATHUR, J., KAUSCHMANN, 
A., ALTMANN, T., REDEI, G.P., NAGY, F., SCHELL, J. and KONCZ, C. (1996). Brassinosteroids rescue the deficiency of CYP90, a cytochrome P450, controlling cell elongation and de-etiolation in Arabidopsis. Cel/85: 171-82.

TALON, M., ZACARIAS, L. and PRIMO-MILLO, E. (1992). Gibberellins and Parthenocarpic Ability in Developing Ovaries of Seedless Mandarins. Plant Physiol 99: 1575-1581.

ULMASOV, T., HAGEN, G. and GUILFOYLE, T.J. (1997a). ARF1, a transcription factor that binds to auxin response elements. Science 276: 1865-8.

ULMASOV, T., LIU, Z.B., HAGEN, G. and GUILFOYLE, T.J. (1995). Composite structure of auxin response elements. Plant Cel/7: 1611-23.

ULMASOV, T., MURFETT, J., HAGEN, G. and GUILFOYLE, T.J. (1997b). Aux/IAA proteins repress expression of reporter genes containing natural and highly active synthetic auxin response elements. Plant Ce//9: 1963-71.

VAN HUIZEN, R., OZGA, J.A. and REINECKE, D.M. (1997). Seed and Hormonal Regulation of Gibberellin 20-Oxidase Expression in Pea Pericarp. Plant Physiol 115: 123-128.

VAN HUIZEN, R., OZGA, J.A., REINECKE, D.M., TWITCHIN, B. and MANDER, L.N. (1995). Seed and 4-chloroindole-3-acetic acid regulation of gibberellin metabolism in pea pericarp. Plant Physiol 109: 1213-7.

VIVIAN-SMITH, A. and KOLTUNOW, A.M. (1999). Genetic analysis of growthregulator-induced parthenocarpy in Arabidopsis. Plant Physiol 121: 437-51.

VIVIAN-SMITH, A., LUO, M., CHAUDHURY, A. and KOLTUNOW, A. (2001). Fruit development is actively restricted in the absence of fertilization in Arabidopsis. Development 128: 2321-31.

VRIEZEN, W.H., ACHARD, P., HARBERD, N.P. and VAN DER STRAETEN, D. (2004). Ethylene-mediated enhancement of apical hook formation in etiolated
Arabidopsis thaliana seedlings is gibberellin dependent. Plant J37: 505-16.

WANG, H., JONES, B., LI, Z., FRASSE, P., DELALANDE, C., REGAD, F., CHAABOUNI, S., LATCHE, A., PECH, J.C. and BOUZAYEN, M. (2005). The tomato Aux/IAA transcription factor IAA9 is involved in fruit development and leaf morphogenesis. Plant Cel/17: 2676-92.

WEIGEL, D. and JURGENS, G. (2002). Stem cells that make stems. Nature 415 751-4.

WEIJERS, D., BENKOVA, E., JAGER, K.E., SCHLERETH, A., HAMANN, T., KIENTZ, M., WILMOTH, J.C., REED, J.W. and JURGENS, G. (2005a). Developmental specificity of auxin response by pairs of ARF and Aux/IAA transcriptional regulators. EMBO J24: 1874-85.

WEIJERS, D., SAUER, M., MEURETTE, O., FRIML, J., LJUNG, K., SANDBERG, G., HOOYKAAS, P. and OFFRINGA, R. (2005b). Maintenance of embryonic auxin distribution for apical-basal patterning by PIN-FORMED-dependent auxin transport in Arabidopsis. Plant Cel/17: 2517-26.

WEIJERS, D., SCHLERETH, A., EHRISMANN, J.S., SCHWANK, G., KIENTZ, M and JURGENS, G. (2006). Auxin triggers transient local signaling for cell specification in Arabidopsis embryogenesis. Dev Cel/ 10: 265-70.

WOODWARD, A.W. and BARTEL, B. (2005). Auxin: regulation, action, and interaction. Ann Bot (Lond) 95: 707-35.

YIN, Z., MALINOWSKI, R., ZIOLKOWSKA, A., SOMMER, H., PLCADER, W. and MALEPSZY, S. (2006). The DefH9-iaaM-containing construct efficiently induces parthenocarpy in cucumber. Cell Mol Biol Lett 11: 279-90.

ZENSER, N., ELLSMORE, A., LEASURE, C. and CALLIS, J. (2001). Auxin modulates the degradation rate of Aux/IAA proteins. ProcNat/Acad SciUSA98: $11795-800$.

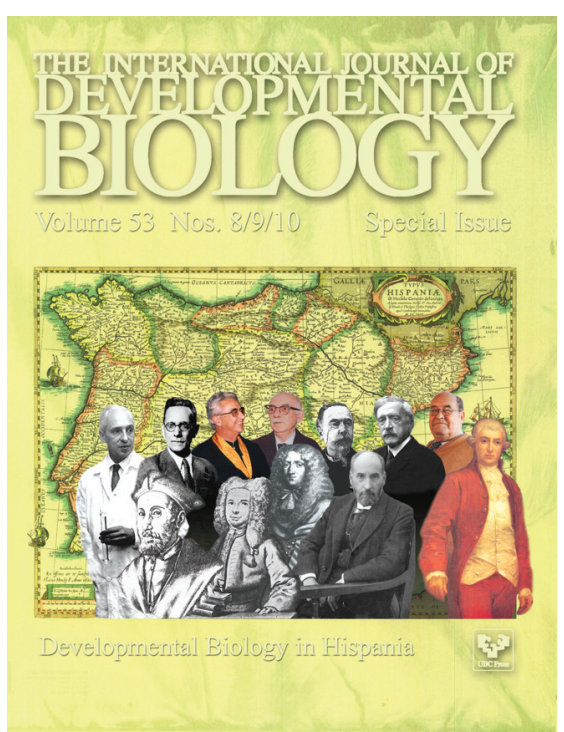




\section{Further Related Reading, published previously in the Int. J. Dev. Biol.}

See our Special Issue Plant Development edited by José Luis Micol and Miguel Angel Blázquez at:

http://www.ijdb.ehu.es/web/contents.php?vol=49\&issue=5-6

See our recent Special Issue Fertilization, in honor of David L. Garbers and edited by Paul M. Wassarman and Victor D. Vacquier at: http://www.ijdb.ehu.es/web/contents.php?vol=52\&issue=5-6

Patterning and morphogenesis of the vertebrate inner ear

Jinwoong Bok, Weise Chang and Doris K. Wu

Int. J. Dev. Biol. (2007) 51: 521-533

Axial patterning in the developing vertebrate inner ear

Tanya T. Whitfield and Katherine L. Hammond

Int. J. Dev. Biol. (2007) 51: 507-520

Genetic control of dorsoventral patterning and neuroblast specification in the Drosophila Central Nervous System Guoyan Zhao, Scott R. Wheeler and James B. Skeath Int. J. Dev. Biol. (2007) 51: 107-115

Where do we stand now? - mouse early embryo patterning meeting in Freiburg, Germany (2005)

Takashi Hiiragi, Vernadeth B. Alarcon, Toshihiko Fujimori, Sophie Louvet-Vallée, Marek Maleszewski, Yusuke Marikawa, Bernard Maro and Davor Solter

Int. J. Dev. Biol. (2006) 50: 581-588

Principles of branch formation and branch patterning in Hydrozoa

Stefan Berking

Int. J. Dev. Biol. (2006) 50: 123-134

Head-tail patterning of the vertebrate embryo: one, two or many unresolved problems?

Claudio D. Stern, Jeroen Charité, Jacqueline Deschamps, Denis Duboule, Anthony J. Durston, Marie Kmita, Jean-François Nicolas, Isabel Palmeirim, Jim C. Smith and Lewis Wolpert

Int. J. Dev. Biol. (2006) 50: 3-15

Antero-posterior patterning of the vertebrate digestive tract: $\mathbf{4 0}$ years after Nicole Le Douarin's PhD thesis

Anne Grapin-Botton

Int. J. Dev. Biol. (2005) 49: 335-347

Genetic control of floral size and proportions

Julia Weiss, Luciana Delgado-Benarroch and Marcos Egea-Cortines

Int. J. Dev. Biol. (2005) 49: 513-525

Regulation of phyllotaxis

Didier Reinhardt

Int. J. Dev. Biol. (2005) 49: 539-546

Preface - Plants develop and grow

José L. Micol and Miguel A. Blázquez

Int. J. Dev. Biol. (2005) 49: 449-452

ULTRACURVATA1, a SHAGGY-like Arabidopsis gene required for cell elongation JM Perez-Perez, MR Ponce, JL Micol Int. J. Dev. Biol. (2001) 45: S51-S52

Interactions between venation pattern formation genes in Arabidopsis thaliana $\mathrm{H}$ Candela, A Martinez-Laborda, JL Micol

Int. J. Dev. Biol. (2001) 45: S35-S36

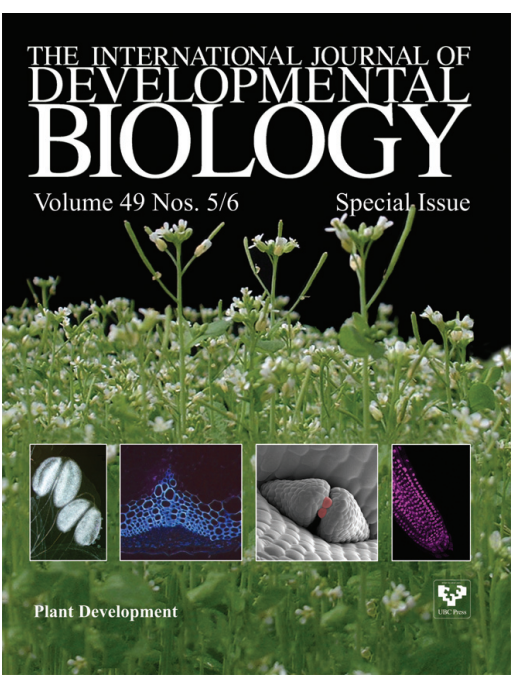

5 yr ISI Impact Factor $(2008)=3.271$

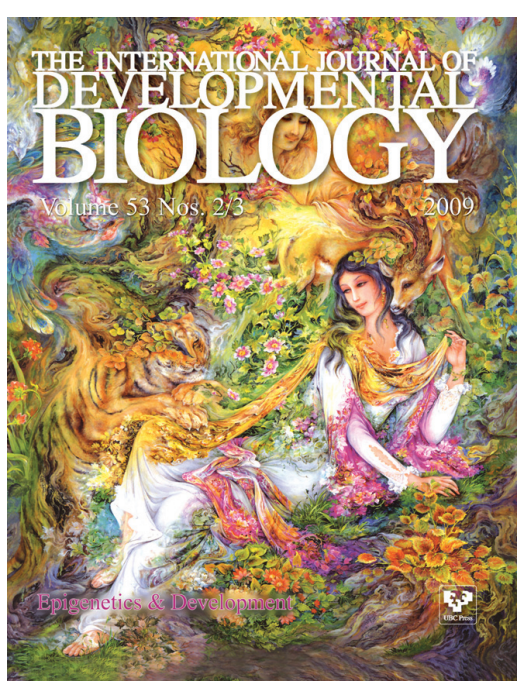

